\title{
Contribution Analysis of ICT (New Generation Network) Investment for Agriculture In Uzbekistan
}

\author{
QiJu Zhu, Tursun Shodiev \\ Tashkent State University of Economics, Uzbekistan \\ Westminster International University in Tashkent, Uzbekistan \\ Email (corresponding author): billzhu0836@sina.com
}

\begin{abstract}
The new generation network and technology is changing the world day by day, so does in area of Agriculture. Agriculture is the basic stone of economic development in the transition countries. In the past decade, Information communication Technology is enriching people's communication, which is the important criteria of knowledge society. In developed countries, ICT for agriculture is quite important. According to last research findings the technology contribution for Agriculture in developed countries is around 70 per cent. In developing countries such kind of research is not provided. The article analysis the contribution of the new generation ICT network investment for agriculture employing the Solow Residual theory and Cobb-Douglas Production function.
\end{abstract}

Keywords: ICT (NGN), Technology Contribution for Agriculture, Cobb-Douglas Produciton Function, Solow Residual Theory

\section{INTRODUCTION}

Obviously ICT(NGN) is very important technology to promote the information transfer efficient and distant connection for rural area. How to value the contributuion for Agriculture?. Via our method and data analysis we will see the relative contribution between ICT(NGN) for agriculture in Uzbekistan. There are two steps to obtain the relative number. First phase we observe the technology contribution for Agriculture (herein after short as the TCA) in Uzbekistan. Cobb-Douglas produciton funciton will be used. Then we use the regression analysis to find out the coefficent between ICT(NGN) investment and TCA.The realtive contribution of ICT/NGN to Agriculture in Uzbekistan will be studied. Although this method is not the give the direct data to show the relationship between ICT/NGN for Agriculture in Uzbekistan, the parameter we obtain also can make sense to give us advice and idea whether and how much somehow the ICT/NGN to promote the Agricutlrue in Uzbekistan.

\section{A BRIEF LITERATURE REVIEW}

There are three kind of production functions, they are Single Output Production Function, Multiple Output Production Function(Faber, et al., 1998), Aggregate Production Functions. Production function used widely as method of economic analysis in the neoclassical tradition. It is believed that Philip Wicksteed (1894) was the first economist to algebraically formulate the relationship between output and inputs as $P$ $=f(x 1, x 2, \ldots, x m)$ although there are some proofs showing that Johann von Thünen was first formulated it in the 1840's (Humphrey, 1997). Technical efficiency and allocation efficiency (see Libenstein et al., 1988) are the two leading concepts of efficiency relating to a production system. Normally people assume that the engineering and managerial problems of technical efficiency have already been addressed and solved, so that analysis can focus on the problems of allocate efficiency (Shephard, 1970). Although the notion of production function assumes that technical efficiency has been achieved, some economists and operations research workers against the hypothesis by what is known as the 'Data Envelopment Analysis' or DEA (Farrel, 1957; Charnes et al., 1978; Banker et al., 1984; Lovell and Schmidt, 1988; Seiford and Thrall, 1990; Emrouznejad, 2001, etc). During the earlier 1950's to the late 1970's production function was developed very fast, which attracted many economists to evolve in and develop the theory. A number of specifications or algebraic forms relating inputs to output were proposed, thoroughly analyzed and used for deriving various conclusions. Especially after the end of the 'capital controversy', search for new specification of production functions slowed down considerably. Our objective in this paper is to use the Single Output Production Function, helped with econometrics methods to find out the correlation and co efficiency among the input of ICT/NGN in Agriculture and Agriculture technology contribution to Agriculture in Uzbekistan. 
Tursun Shodiev, QiJu Zhu

Contribution Analysis of ICT (New Generation Network) Investment for Agriculture In Uzbekistan

\section{Methodology}

In the data collection, we persue obtain the Agriculture input facots according to our methods, which based the Solow residual theory. Those data are including the Agriculture: Agriculture GDP increaing rate, Material output elasticity(herein after short for MIR), the increasing rate of Materail expenditure(herein after-short for Em), Labor force growth rate(herein after short for LGR), Land output elasticity--a, Land growth rate (herein after short for LGR), Land output elasticity- $\beta$. Uzbekistan is a highly agrarian country, with its rural population at more than $60 \%$ and agriculture accounting for around $30 \%$ in employment and $20 \%$ in GDP(World Bank, 2013). As is typical of economies dependent on agriculture. In terms of developments over time, the share of agriculture in GDP has fluctuated between $20 \%$ and $35 \%$ since 1992, showing a definite downward trend during the last twenty years although the Agriculture GDP in 2012 is 2.13 times as much as the data in 1992 because the GDP grows 3.93 times sine year 1992. It was meaning, the remaining sectors, such as: industry, service increase much faster than Agriculture, and the country is going industralization.

Agricultural transition in Uzbekistan is driven by a process of land reform, which involves redistribution of land among producers and concomitant changes in farm structure (Lerman, 2007). The country's agricultural systems underwent significant structural changes resulting in total agricultural output dropping to $-19.07 \%$ by 1996 . In the begaining of land transition showed in the below chart, the Agriculture growth rate and Agriculture GDP (graph 1) is variable largely until 2002. However, with the implementation of land distribution initiatives and the engagement of an increasing number of households in agriculture and crop diversification, output has since increased significantly during 2003 and 2007, and has surpassed output levels attained in 1991.

The share of rural population, shown in graph 2, is steadily increasing over time due to higher population growth rates in rural areas from a constant $60 \%$ up to 1990 to $64 \%$ in 2004-2006. The share of agricultural employment also remained steady at $40 \%$ up to 1990 , but after a slight increase to $44 \%$ in the begaining years of transition (1991-1993) the trend changed to a downward slide. The share of agriculture in total employment had dropped to $25.8 \%$ by 2012 (curve, green line below ). Usually, agricultural employment keeps steady around $40 \%$, but the situation changes from 2008, and the opposing trends sharply dropping down from $38 \%$ to $27 \%$ in 2009 . In the past a few years, the number is slightly decreasing. On the other hand, the total number of employment in Uzbeksitan is rasing stable from 1991 to 2007, then in 2008 the total number of employee in Uzbeksitan dropped down 1.5 Million since the number of agriculture employee came down.



Graph 1: Agriculture GDP Growth Rate in Uzbekistan during 1992-2012 (World Bank statistics) 
Tursun Shodiev, QiJu Zhu

Contribution Analysis of ICT (New Generation Network) Investment for Agriculture In Uzbekistan

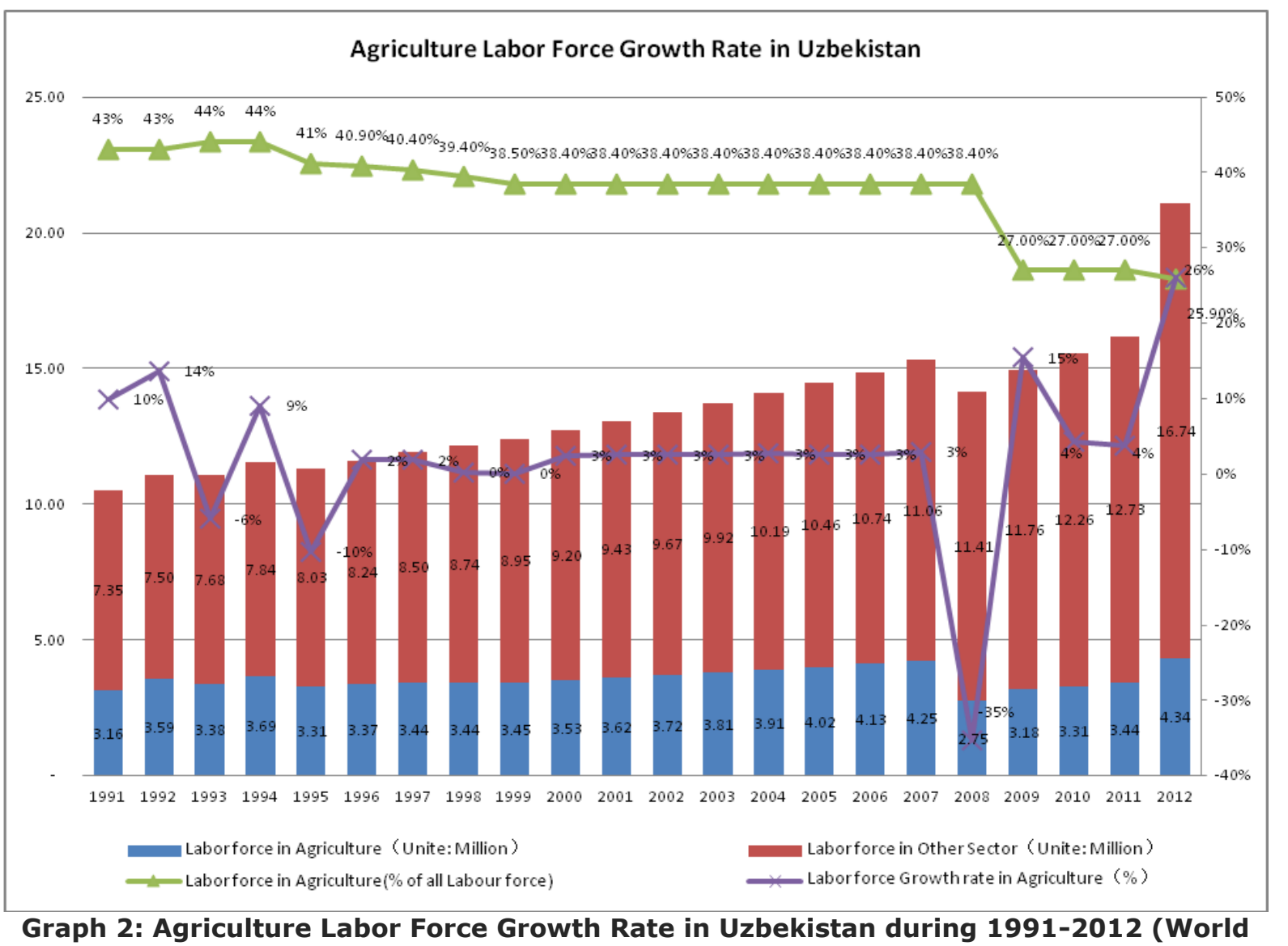

Bank/CIA)

During 2008 and 2012, agriculture employee raising quickly from 2.75 million to 4.34 million, but the percenge of agriculture employee descend from $27 \%$ to $25.9 \%$ because the employee in the other sector is ascending much faster than agriculture labor force.

From graph 2, we can see that there are 3 phases of the growth rate trend of Labor force in Agriculture. The first phase from 1991 to 1996, the labour force growth rate is fluctuate from $10 \%$ in 1991 to $14 \%$ in 1992 , then $-6 \%$ in $1993,9 \%$ in $1994,-10 \%$ again in 1996 . The first phase from 1997 to 2007 , the growth rate of labor force in Agriculture is quite stable around 3\%. The third phase from 2008 to 2012 , the labor force growth rate fall down from $3 \%$ in 1997 to $-35 \%$ in 2008 , then bonce back to $13 \%$ in 2009. In year 2010 and 2012, the number keep 4\%, but in year 2012, it is increased to $26 \%$.

Agricultural land refers to the share of land area that is arable, under permanent crops, and under permanent pastures. Arable land includes land defined by the FAO as land under temporary crops (double-cropped areas are counted once), temporary meadows for mowing or for pasture, land under market or kitchen gardens, and land temporarily fallow. Land abandoned as a result of shifting cultivation is excluded. Land under permanent crops is land cultivated with crops that occupy the land for long periods and need not be replanted after each harvest, such as cocoa, coffee, and rubber. This category includes land under flowering shrubs, fruit trees, nut trees, and vines, but excludes land under trees grown for wood or timber. Permanent pasture is land used for five or more years for forage, including natural and cultivated crops.

The total land area of Uzbekistanamounts, showed in graph 3, to 44.9 million ha of which 4.3 million ha are irrigated, 3.3 million ha being irrigated arable land(following graph) and one million ha being irrigated pasture. It was stable druing 1993 to 1997 , but sharply drop down to 27 , say, $-17.89 \%$ less than the prior year in 1997, and keep relative instance since 1998. The last measured in Uzbeksitan at 26.651 in 2009 according to World Bank in 2002 (www.tradingeconomics.com). In 2002, The irrigated land is of paramount significance for the agriculture and economy of the country. The permanent pasture area amounts to 23.5 million ha accounting for over 80 percent of all agricultural land (SCLR, 2002). In our research, we samply take the irrigated land as the data for our analysis. 
Tursun Shodiev, QiJu Zhu

Contribution Analysis of ICT (New Generation Network) Investment for Agriculture In Uzbekistan

Another important Agriculture input factors is Agriculture Material, which is including but not limited as water usage, seeds, tractor and machinery-own and rented fertilizer-fertilizer, organic manure, pesticides and herbicides use (www ageconsearch.umn.edu). Agricultural machinery refers to the number of wheel and crawler tractors (excluding garden tractors) in use in agriculture at the end of the calendar year specified or during the first quarter of the following year. This page has the latest values, historical data, forecasts, charts, statistics, an economic calendar and news for Agricultural machinery tractors in Uzbekistan (World Bank, www.tradingeconomics.com). In Uzbekistan, Agriculture productions are mainly for cotton and wheat, and it will take most of fertilizer, tractor and machinery, water and seeds. For the water, some area depends on the nature rain to water the land, some area use irragation sytem. So the Material input is difficulty to obtain the exactlly number. We can compare Turkey cotton input and energy analysis to achieve how much percentage energy of Material input, then we can get the relative real coefficient number of material input in Agriculture in Uzbekistan.

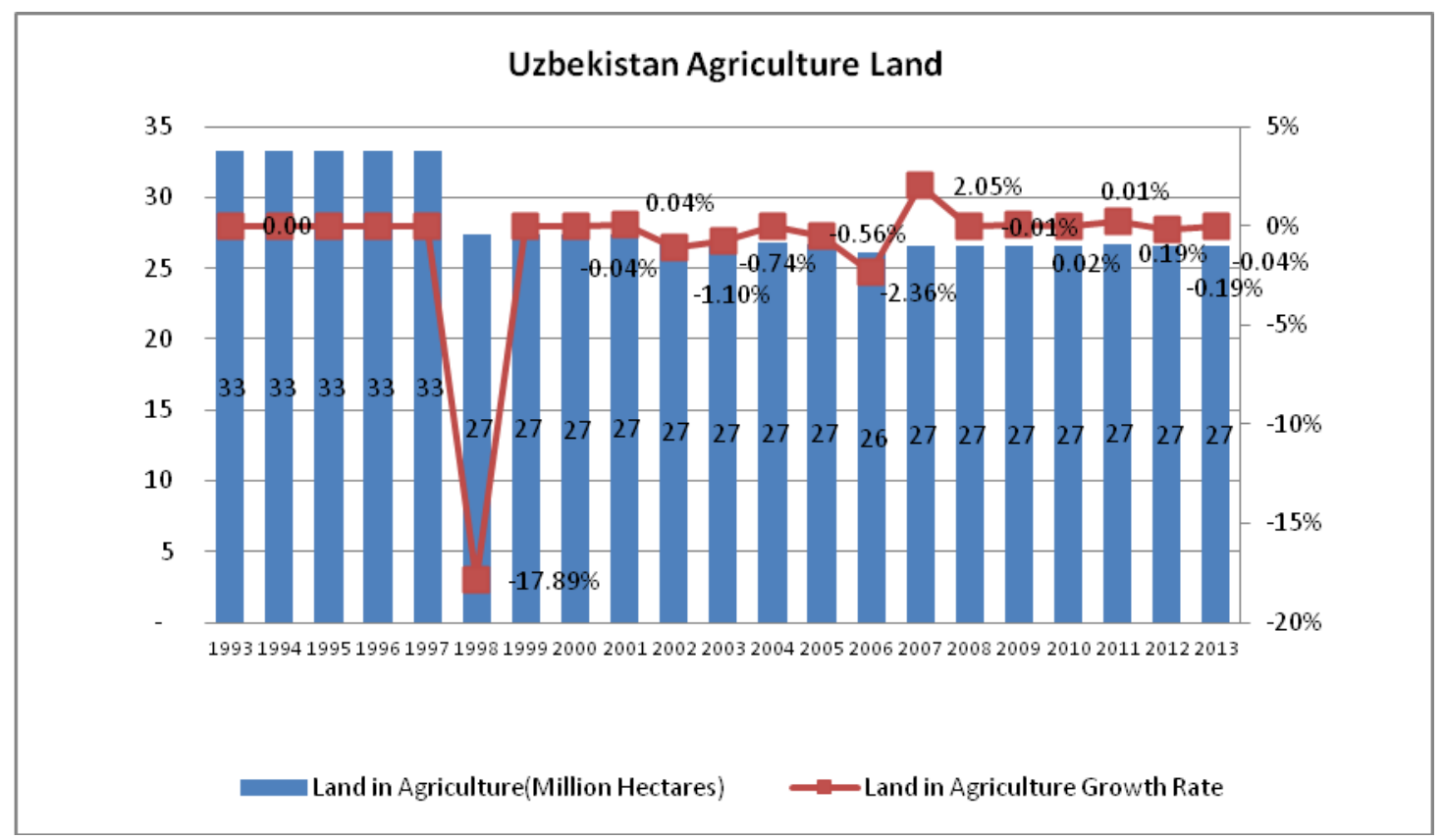

Graph 3: Uzbekistan Agriculture Land during 1993-2013

The following table (table 1) shows Energy consumption and output for cotton production (MJ/ha), we will see the mainly material input for cotton in Turkey are: seeds, labour, fertilizer, pesticides, machinery, diesel, and water for irrigation (Ibrahim, 2004). The advantage of the research is that the material input from different types are transferred into number of energy, the initial relationship of inputs will clearly observed.

The study was to find out the direct input energy and indirect energy in per hectare in cotton production and compare with input costs. During the process before all input converted into cost, energy was the media to be used to show the material input. It is the right data we need to be used to consider the same material input relation in Uzbekistan since the energy consumse will fair to explain the material input without affected by price level. It also sought to analyse the effect of farm size. The data of table 1 were collected from sixty five farmers using a face to face questionnaire. The sample farms were selected through a stratified random sampling technique.

The results revealed that cotton production consumed a total of $49.73 \mathrm{GJ} / \mathrm{ha}$ of which diesel energy consumption was $31.1 \%$ followed by fertilizer and machinery energy. From the most important input items were seeds, labour, machinery costs, diesel water and pesticide above, the labour will not take account our Material expenditure since labour force is caculated as individual factor in our research. Large farms were more successful in energy productivity, use efficiency and economic performance. Here we use the average number. 
Tursun Shodiev, QiJu Zhu

Contribution Analysis of ICT (New Generation Network) Investment for Agriculture In Uzbekistan

Table 1: Weighted average Input of farm in Turkey

\begin{tabular}{|c|c|c|c|c|c|}
\hline \multirow{2}{*}{$\begin{array}{l}\text { Inputs Farm size groups } \\
\text { (ha) Weighted average }\end{array}$} & \multicolumn{3}{|c|}{ Farm size groups (ha) } & \multicolumn{2}{|c|}{ Weighted average } \\
\hline & $0.1-5.0$ & $5.1-12.0$ & $12.1+$ & Quantity & $(\%)$ \\
\hline Seed & 562.9 & 631.3 & 616.0 & 605.3 & 1.2 \\
\hline Labor & $1,477.6$ & $1,407.3$ & $1,480.0$ & $1,449.8$ & 2.9 \\
\hline Land prep. and planting & 8.4 & 6.5 & 6.1 & 6.9 & 0.0 \\
\hline Fertilizer application & 6.9 & 7.3 & 4.7 & 6.5 & 0.0 \\
\hline Spraying & 26.3 & 12.3 & 7.1 & 15.1 & 0.0 \\
\hline Irrigation & 100.5 & 73.9 & 44.1 & 73.9 & 0.2 \\
\hline Hoeing & 383.6 & 399.3 & 485.9 & 418.9 & 0.8 \\
\hline Harvesting & 854.6 & 835.0 & 864.8 & 849.7 & 1.7 \\
\hline Transporting to farm & 12.2 & 7.6 & 6.9 & 8.8 & 0.0 \\
\hline Drivers & 85.3 & 65.5 & 60.6 & 70.2 & 0.1 \\
\hline Fertilizer & $17,359.5$ & $12,345.4$ & $\begin{array}{l}13,925 \\
3\end{array}$ & $14,354.1$ & 28.9 \\
\hline Nitrogen & $16,143.8$ & $11,465.5$ & $\frac{12,544}{2}$ & $13,229.0$ & 26.6 \\
\hline Phosphorus & 916.9 & 561.7 & 962.4 & 784.8 & 1.6 \\
\hline Potassium & 298.8 & 318.3 & 418.8 & 340.4 & 0.7 \\
\hline Pesticides & 393.4 & 450.4 & 418.8 & 426.5 & 0.9 \\
\hline Insecticides & 220.3 & 247.9 & 270.9 & 248.2 & 0.5 \\
\hline Fungicides & 1.8 & 5.4 & 1.6 & 3.5 & 0.0 \\
\hline Herbicides & 171.4 & 197.1 & 146.2 & 174.8 & 0.4 \\
\hline Machinery & $14,842.5$ & $12,681.5$ & $\begin{array}{l}12,178 \\
9\end{array}$ & $13,209.7$ & 26.6 \\
\hline Plough & $2,183.3$ & $2,127.3$ & $1,791.4$ & $2,071.3$ & 4.2 \\
\hline Discing & $2,955.9$ & $1,925.8$ & $2,194.5$ & $2,328.9$ & 4.7 \\
\hline Harrow & 209.0 & 334.4 & 397.1 & 313.5 & 0.6 \\
\hline Land plane & $2,054.0$ & $1,729.7$ & $1,513.4$ & $1,783.7$ & 3.6 \\
\hline Drilling & 601.9 & 511.6 & 511.6 & 541.7 & 1.1 \\
\hline Furrow cultivator & 313.5 & 313.5 & 285.0 & 313.5 & 0.6 \\
\hline Fertilizer spreader & 827.6 & 601.9 & 225.7 & 526.7 & 1.1 \\
\hline Sprayer & 451.4 & 571.8 & 285.9 & 451.4 & 0.9 \\
\hline Hoeing by cultivator & $4,827.9$ & $4,263.6$ & $4,765.2$ & $4,577.1$ & 9.2 \\
\hline Trailer & 418.0 & 301.9 & 209.0 & 301.9 & 0.6 \\
\hline Diesel & $17,602.5$ & $15,535.9$ & $\begin{array}{l}12,996 \\
3\end{array}$ & $15,468.4$ & 31.1 \\
\hline Water for irrigation & $4,504.5$ & $4,221.0$ & $3,913.0$ & $4,223.0$ & 8.5 \\
\hline Total energy input & $56,743.0$ & $47,272.8$ & $5,528.3$ & $49,736.9$ & 100.0 \\
\hline Total energy output & $36,930.5$ & $35,965.2$ & $\begin{array}{l}37,609 . \\
0\end{array}$ & $36,729.9$ & - \\
\hline Energy output-input ratio & 0.7 & 0.8 & 0.8 & 0.7 & - \\
\hline $\begin{array}{l}\text { Energy productivity } \quad(\mathrm{kg} \\
\text { seed/MJ) }\end{array}$ & 0.1 & 0.1 & 0.1 & 0.1 & - \\
\hline
\end{tabular}




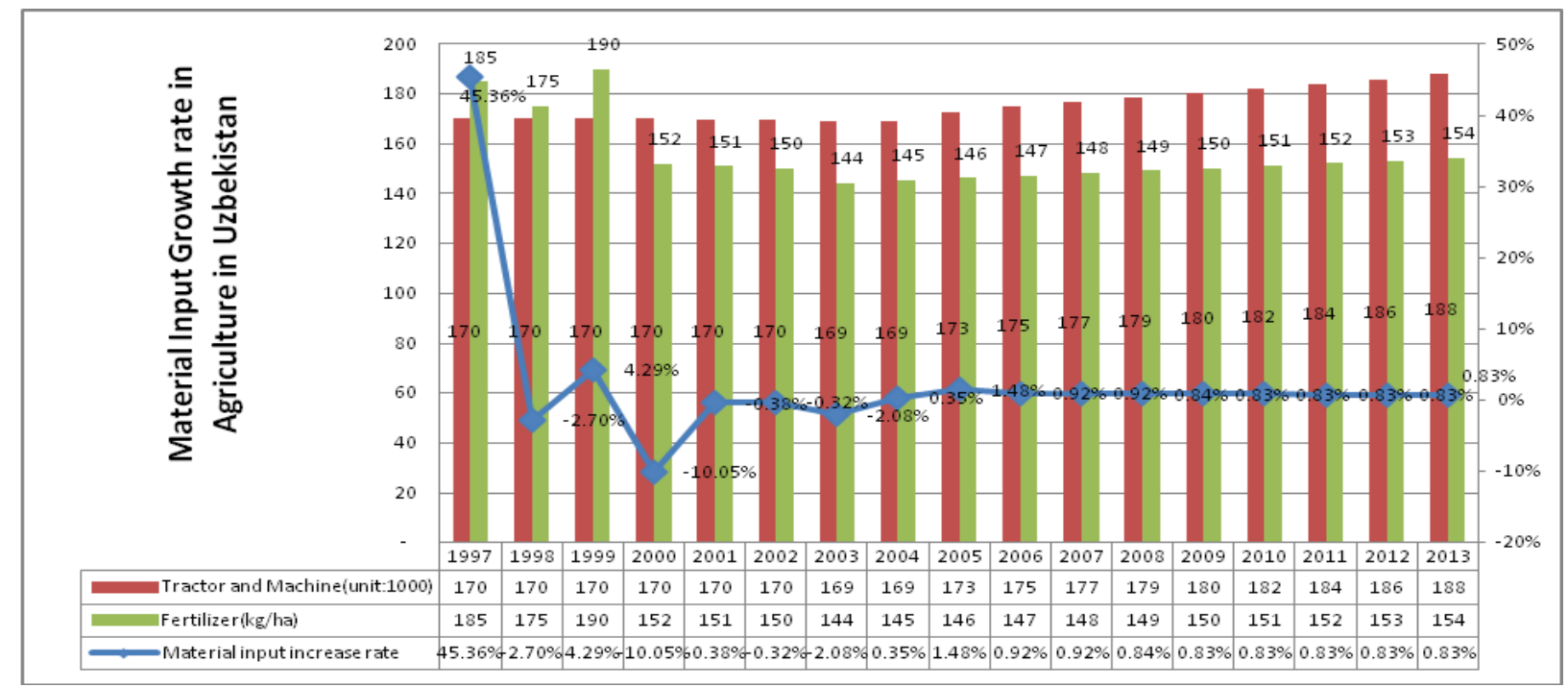

Graph 4: Material Input Growth rate in Agriculture in Uzbekistan during 1997 to 2013

From graph 4, we will find out that the tractor and machinery input in agriculture keep increasing from 1997 to 2013, so does the chemical fertilizer although it is dropped down during 1997 and 2002 . The total material input growth rate in Agriculture in Uzbeksitan have different stroy, the number of material input jumped down from $45.36 \%$ in 1997 to $-10 \%$ in 2000 , it keep variable around $0 \%$, backto positive,say, $0.35 \%$ since year 2005 , after that the material input growth rate maitain a number less than $1 \%$.

\section{DATA ANALYSIS}

Compared the data we collected obove, shown in table 2, the agriculture GDP growth rate, Labor force in Agriculture growth rate, land in Agriculture and Material inpute growth rate are all fluntuation larg in the 1990s. The Agriculture land usage and Material input are relative stable. In the past 6 years from 2007 to 2012, the variable of the data are obvisouly. Through the data changes, it companyed the land transfer reform and Agriculture production culvation structure adjustment. Our research focus on the contruction of ICT/NGN investment to Agriculture, rather than the other factors. So we choose the data during 2002 to 2012 (see the table 2), and the period the ICT investment is booming up fastly according to our research in Chapter III.

Table 2: The Statistic of key factos of Agriculture in Uzbekistan during 2002 to 2012

\begin{tabular}{|l|l|l|l|l|l|l|l|l|l|l|l|}
\hline ITEM & 2002 & $\begin{array}{l}200 \\
3\end{array}$ & $\begin{array}{l}200 \\
4\end{array}$ & 2005 & $\begin{array}{l}200 \\
6\end{array}$ & 2007 & 2008 & 2009 & 2010 & 2011 & 2012 \\
\hline $\begin{array}{l}\text { Land Growth } \\
\text { Rate in } \\
\text { Agriculture (\%) }\end{array}$ & -1.03 & 0.72 & -4.18 & -0.34 & 8.11 & 11.22 & 20.04 & 11.62 & 7.32 & 16.21 & 16.31 \\
\hline $\begin{array}{l}\text { Labor Force } \\
\text { Growth Rate in } \\
\text { Agriculture (\%) }\end{array}$ & 2.56 & 2.53 & 2.70 & 2.67 & 2.69 & 3.01 & -35.3 & 15.49 & 4.28 & 3.84 & 26.07 \\
\hline $\begin{array}{l}\text { Material Input } \\
\text { Growth Rate in } \\
\text { Agriculture (\%) }\end{array}$ & -0.32 & -2.08 & 0.35 & 1.48 & 0.92 & 0.92 & 0.84 & 0.83 & 0.83 & 0.83 & 0.83 \\
\hline
\end{tabular}

The Cobb-Douglas Production Function for the elasticities

To obtain Ratio of Science and Technology Progress(short for Rstp), we shall caculate the coefficent of Material expenditure, land, and labor in Agriculture. Cobb Douglas production function is employed. The steps below describe the process. 


\section{The Cobb Douglas Production Function}

Suppose the Cobb-Douglas production function describes how a particular economy's output level $Y$ is determined from the inputs $\mathrm{L}$ and $\mathrm{K}$ :

$$
\text { (1) } \quad Y(L, K)=A L^{a_{1}} K^{a_{2}}, \mathrm{~A}>0,0<\mathrm{a} 1<1,0<\mathrm{a} 2<1
$$

The variables $A, a 1$, and a2 describe the economy's technology. The variable $A$ can be thought of as the general level of technology. The production function indicates that an increase in the parameter A---a technological improvement---will increase output.The technological parameters a1 and a2 measure the respective contributions of $\mathrm{L}$ and $\mathrm{K}$ to the production process, as will now be shown more carefully. In past dacades, tangible material input is largely affecting the Agriculture output, for example: Fertilizer, Machine and tractor, seeds, etc. We define the material expenditure as $M$, and the CobbDouglas production function refined as described below:

$$
Y(L, K, M)=A L^{a_{1}} K^{a_{2}} M^{a_{3}}, \mathrm{~A}>0,0<\mathrm{a} 1<1,0<\mathrm{a} 2<1,0<\mathrm{a} 3<1
$$

The variables $M$ is the material expenditure and input. The remaining factores are remaining the same meaning as equation.

\section{Refine the Cobb Douglas Production Function and calculation the elasticities}

By applying econometric tools to our Cobb-Douglas production function, we can try to obtain estimates of the parameters $A, a 1, a 2$ and a3. In fact, this is a classic econometric problem.

Our production function indicates the output level $Y$ depends upon employment $L$, capital $\mathrm{K}$ and material input $M$. By gathering data on output, employment, capital stock, and material input we could regress $Y$ on $\mathrm{L}, \mathrm{K}$, and $\mathrm{M}$. However, such a regression would not be consistent with the Cobb Douglass production function relationship, but rather would be consistent with the linear production function relationship.

$$
Y=a_{1} L+a_{2} K+a_{3} M
$$

The regression would provide us with estimates of $a_{1}, a_{2}$, and $a_{3}$. The estimate of $a_{1}$ would be the estimate of the marginal product of labor for the linear production function (3). Notice this estimate would be a constant, meaning production does not exhibit diminishing returns. Indeed, the linear production function (3) indicates marginal labor productivity cannot decrease as employment increase, nor increase. The same is true with the marginal productivity of capital. Moreover, the level of capital does not impact labor productivity in the linear production function (3) as it does in the Cobb Douglas production function (3). Economists have long favored using the Cobb-Douglas production function over the linear production function because the Cobb Douglas allows for diminishing returns and because it allows the level of one input (e.g., capital) to affect the productivity of another input (e.g., labor).

In the Cobb-Douglas production function $Y=A L^{a_{1}} K^{a_{2}} M^{a_{3}}$, there is a nonlinear relationship between the inputs $\mathrm{L}$ and $\mathrm{K}$ and the output $\mathrm{Y}$, and the three input interact.To estimate the parameters $a_{1}, a_{2}, a_{3}$ and $A$, the nonlinear Cobb Douglas must be linearized. This is possible, which is another reason why the Cobb-Douglas is so attractive. Taking the natural log of both sides of $Y=A L^{a_{1}} K^{a_{2}}$, we obtain

$$
\ln (Y)=\ln (A)+a_{1} \ln (L)+a_{2} \ln (K)+a_{3} \ln (M)
$$

Using available data, we can take the natural log of each data series to create variables that are in the log levels rather than the levels. Regression visa SPASS softwear to the $\ln (Y)$ on the $\ln (L)$ the $\ln (K)$, and the $\ln (M)$, we obtain the coefficent numbers as in the below table 3 . 
Tursun Shodiev, QiJu Zhu

Contribution Analysis of ICT (New Generation Network) Investment for Agriculture In Uzbekistan

Table 3: The Coefficient and Corelation calculation of Agriculture key factors during 1997 to 2013 (World Bank/SPSS calculation)

\begin{tabular}{|c|c|c|c|c|c|c|c|c|}
\hline Year & $\begin{array}{l}\text { Material } \\
\text { Expenditure in } \\
\text { Agriculture } \\
\text { (Billion USD) }\end{array}$ & $\begin{array}{l}\text { Land in Agriculture ( } \\
\text { Million Hectar ) }\end{array}$ & $\begin{array}{l}\text { Labour in Agriculture ( } \\
\text { Million ) }\end{array}$ & $\begin{array}{l}\text { Agriculture } \\
\text { GDP (Billion } \\
\text { USD) }\end{array}$ & A & A1 & A2 & A3 \\
\hline 1997 & 1.91 & 33.31 & 3.44 & 3.81 & 0.28 & 1.52 & 0.54 & 0.58 \\
\hline 1998 & 1.89 & 27.35 & 3.44 & 3.67 & 0.28 & 1.44 & 0.54 & 0.56 \\
\hline 1999 & 2.21 & 27.35 & 3.45 & 3.9 & 0.34 & 1.44 & 0.54 & 0.59 \\
\hline 2000 & 1.98 & 27.34 & 3.53 & 3.96 & 0.30 & 1.44 & 0.55 & 0.60 \\
\hline 2001 & 1.97 & 27.35 & 3.62 & 3.88 & 0.30 & 1.44 & 0.56 & 0.59 \\
\hline 2002 & 1.92 & 27.05 & 3.72 & 3.88 & 0.28 & 1.43 & 0.57 & 0.60 \\
\hline 2003 & 1.87 & 26.85 & 3.81 & 3.71 & 0.27 & 1.43 & 0.58 & 0.60 \\
\hline 2004 & 2 & 26.85 & 3.91 & 3.7 & 0.30 & 1.43 & 0.59 & 0.57 \\
\hline 2005 & 2.24 & 26.7 & 4.02 & 4 & 0.35 & 1.43 & 0.60 & 0.60 \\
\hline 2006 & 2.69 & 26.07 & 4.13 & 4.45 & 0.43 & 1.41 & 0.62 & 0.65 \\
\hline 2007 & 3 & 26.61 & 4.25 & 5.34 & 0.48 & 1.43 & 0.63 & 0.73 \\
\hline 2008 & 3.22 & 26.6 & 2.75 & 5.96 & 0.51 & 1.42 & 0.44 & 0.78 \\
\hline 2009 & 3.74 & 26.61 & 3.18 & 6.4 & 0.57 & 1.43 & 0.50 & 0.81 \\
\hline 2010 & 4.35 & 26.61 & 3.31 & 7.44 & 0.64 & 1.43 & 0.52 & 0.87 \\
\hline 2011 & 4.87 & 26.66 & 3.44 & 8.65 & 0.69 & 1.43 & 0.54 & 0.94 \\
\hline 2012 & 5.25 & 26.61 & 4.34 & 9.67 & 0.72 & 1.43 & 0.64 & 0.99 \\
\hline 2013 & 5.29 & 26.6 & 4.76 & 10.43 & 0.72 & 1.42 & 0.68 & 1.02 \\
\hline
\end{tabular}

Table 4: The final estimation table 
Tursun Shodiev, QiJu Zhu

Contribution Analysis of ICT (New Generation Network) Investment for Agriculture In Uzbekistan

\begin{tabular}{|c|c|c|c|c|}
\hline Variable & Coefficient & Std. Error & t-Statistic & Prob. \\
\hline $\mathrm{C}$ & -0.330260 & 0.445729 & -0.740944 & 0.4719 \\
\hline LABOR & 0.095433 & 0.114842 & 0.830994 & 0.4210 \\
\hline LAND & 0.397279 & 0.296816 & 1.338468 & 0.2037 \\
\hline $\mathrm{K}$ & 0.943074 & 0.040725 & 23.15699 & 0.0000 \\
\hline R-squared & 0.979191 & \multicolumn{2}{|c|}{ Mean dependent var } & 0.707134 \\
\hline Adjusted R-squared & 0.974389 & \multicolumn{2}{|c|}{ S.D. dependent var } & 0.160362 \\
\hline S.E. of regression & 0.025663 & \multicolumn{2}{|c|}{ Akaike info criterion } & -4.285191 \\
\hline Sum squared resid & 0.008562 & \multicolumn{2}{|c|}{ Schwarz criterion } & -4.089141 \\
\hline Log likelihood & 40.42413 & \multicolumn{2}{|c|}{ Hannan-Quinn criter. } & -4.265703 \\
\hline F-statistic & 203.9129 & \multicolumn{2}{|c|}{ Durbin-Watson stat } & 1.293923 \\
\hline Prob(F-statistic) & 0.000000 & & & \\
\hline
\end{tabular}

\section{Ratio of Agriculture Technology Contribution (short for RATC)}

As we discussed in chapter II, Agriculture technical contribution ratio(TCA) is generalized explained as the contribution of agriculture technology development to agriculture output growth rate, which including the benefit of science technology development and agriculture policy amending, management and service progress (Fan Sheng, 2007). Here we set:

RATC $=($ RAGDP-MIR*Em-LGR*a-LGR* $\beta) /$ RAGDP

Where:

$\mathbf{R}_{\text {ATC: }}$ The Agriculture Tecnology Contribution ratio

$\mathbf{R}_{\text {AGDR }}$ : Agriculture GDP increaing rate

$\mathbf{M}_{\mathrm{IR}}$ : Material output elasticity

Em: The increasing rate of Materail expenditure

$\mathbf{L}_{\mathbf{G R}}$ : Labor force growth rate

a: Labor output elasticity

$\mathbf{L}_{\mathbf{G R}}$ : Land growth rate

$\beta$ : Land output elasticity

According to our caculation, coefficient of MIR, $a, \beta$ are $0.943074,0.397279,0.095433$. RATC yearly result as in the table 4.

From table 4, the table shows that the data of RATC is fluctent quite hard during the period of 1997 to 2004. If we check the agricultur industry, we will see during the stage, land transit and and cotton/wheat cultivation reconstructure are ongoing. The GDP of Agriculture changes up and down frenquently.

From 2004 to 2013, the data tends to relative stable, but the RATC vary is still obviously. According to Chapter III, ICT/NGN invest in the sociey is booming up. Our research is checking the ICT/NGN investment to contribute the ratio of Agriculture Technology Contribution. So we shall focus on the data during 2004 to 2013. 
Tursun Shodiev, QiJu Zhu

Contribution Analysis of ICT (New Generation Network) Investment for Agriculture In Uzbekistan

Table 4: The $\mathbf{R}_{\text {stp }}$ and $\mathbf{R}_{\text {ATC }}$ caculation during 1997 to 2008 in Uzbekistan

\begin{tabular}{|c|c|c|c|c|c|c|c|c|c|}
\hline Year & $\begin{array}{l}\text { Agricultu } \\
\text { re GDP } \\
\text { Growth } \\
\text { rate }(\%)\end{array}$ & a & $\beta$ & $M_{I R}$ & $\begin{array}{l}\text { LGR*a } \\
(\%)\end{array}$ & $\begin{array}{l}\text { LGR* } \beta \\
(\%)\end{array}$ & $\begin{array}{l}\mathrm{M}_{\mathrm{IR}} * \mathrm{Em} \\
(\%)\end{array}$ & $\begin{array}{l}\text { Rstp } \\
(\%)\end{array}$ & $\begin{array}{l}\text { RATC } \\
(\%)\end{array}$ \\
\hline 1997 & 23.14 & 1.5226 & 0.5366 & 0.5809 & $-7.58 x$ & 0.18 & 42.78 & -12.24 & -52.91 \\
\hline 1998 & -2.72 & 1.4370 & 0.5366 & 0.5647 & 9.19 & 0.03 & -2.55 & -9.39 & 345.50 \\
\hline 1999 & 7.08 & 1.4370 & 0.5378 & 0.5911 & -1.08 & 0.01 & 4.04 & 4.11 & 58.07 \\
\hline 2000 & 2.49 & 1.4368 & 0.5478 & 0.5977 & 2.81 & 0.24 & -9.48 & 8.92 & 358.12 \\
\hline 2001 & -1.03 & 1.4370 & 0.5587 & 0.5888 & 0.99 & 0.24 & -0.35 & -1.91 & 185.48 \\
\hline 2002 & 0.72 & 1.4322 & 0.5705 & 0.5888 & -0.41 & 0.24 & -0.30 & 1.19 & 164.26 \\
\hline 2003 & -4.18 & 1.4289 & 0.5809 & 0.5694 & 0.29 & 0.24 & -1.96 & -2.75 & 65.78 \\
\hline 2004 & -0.34 & 1.4289 & 0.5922 & 0.5682 & -1.66 & 0.26 & 0.33 & 0.73 & 214.23 \\
\hline 2005 & 8.11 & 1.4265 & 0.6042 & 0.6020 & -0.14 & 0.26 & 1.40 & 6.60 & 81.33 \\
\hline 2006 & 11.22 & 1.4161 & 0.6160 & 0.6484 & 3.22 & 0.26 & 0.86 & 6.88 & 61.30 \\
\hline 2007 & 20.04 & 1.4251 & 0.6284 & 0.7275 & 4.46 & 0.29 & 0.87 & 14.42 & 71.98 \\
\hline 2008 & 11.62 & 1.4249 & 0.4393 & 0.7753 & 7.96 & -3.37 & 0.79 & 6.24 & 53.70 \\
\hline 2009 & 7.32 & 1.4251 & 0.5024 & 0.8069 & 4.62 & 1.48 & 0.79 & 0.44 & 6.02 \\
\hline 2010 & 16.21 & 1.4251 & 0.5198 & 0.8716 & 2.91 & 0.41 & 0.79 & 12.11 & 74.69 \\
\hline 2011 & 16.31 & 1.4259 & 0.5366 & 0.9370 & 6.44 & 0.37 & 0.78 & 8.72 & 53.46 \\
\hline 2012 & 11.79 & 1.4251 & 0.6375 & 0.9854 & 6.48 & 2.49 & 0.78 & 2.04 & 17.30 \\
\hline 2013 & 7.86 & 1.4249 & 0.6776 & 1.0183 & 4.68 & 0.93 & 0.78 & 1.46 & 18.60 \\
\hline
\end{tabular}

The average RATC from the year 2004 to 2013 is $48.71 \%$, it was meaning the contribution of technology and science to Agriculture output is 48.71\%, it is the level in year 2005 in China (Wang, 2006). The number in China in 2013 is $55.2 \%$, and it is around $80 \%$ in USA and develped countries in the world.

\section{THE REgRESSION ANALYSIS BETWEEN RATC THE ICT/NGN INVESTMENT}

The regress analysis will try to find the relation between ICT/NGN investment in Uzbekistan and the contribution of science and technology progress in Uzbeksitan. As Chapter III observed, ICT/NGN will do contribution for the Economy productivity, so does Agriculture. The transfer mechanism from ICT/NGN takes time and theorically there is jet lag, but for a period of analysis, the result may make sense. Statistical data shows, the ICT/NGN usage increase sharply from year 2006 to year 2011, it companyed with the investment value of ICT/NGN. Besause of the jet lag phenomenon, in ICT/NGN area, the registry number and real clients are normaly $70 \%-80 \%$ relations, the investment in ICT/NGN will have 1 2 years construction perios. we use the ICT/NGN investment data from year 2004 to year 2013. The following graph 5 is the data of ICT/NGN investment compared with Ratio of Agriculture Technology Contribution in Uzbekistan/Agriculture from year 2005 to 2013. 
Tursun Shodiev, QiJu Zhu

Contribution Analysis of ICT (New Generation Network) Investment for Agriculture In Uzbekistan

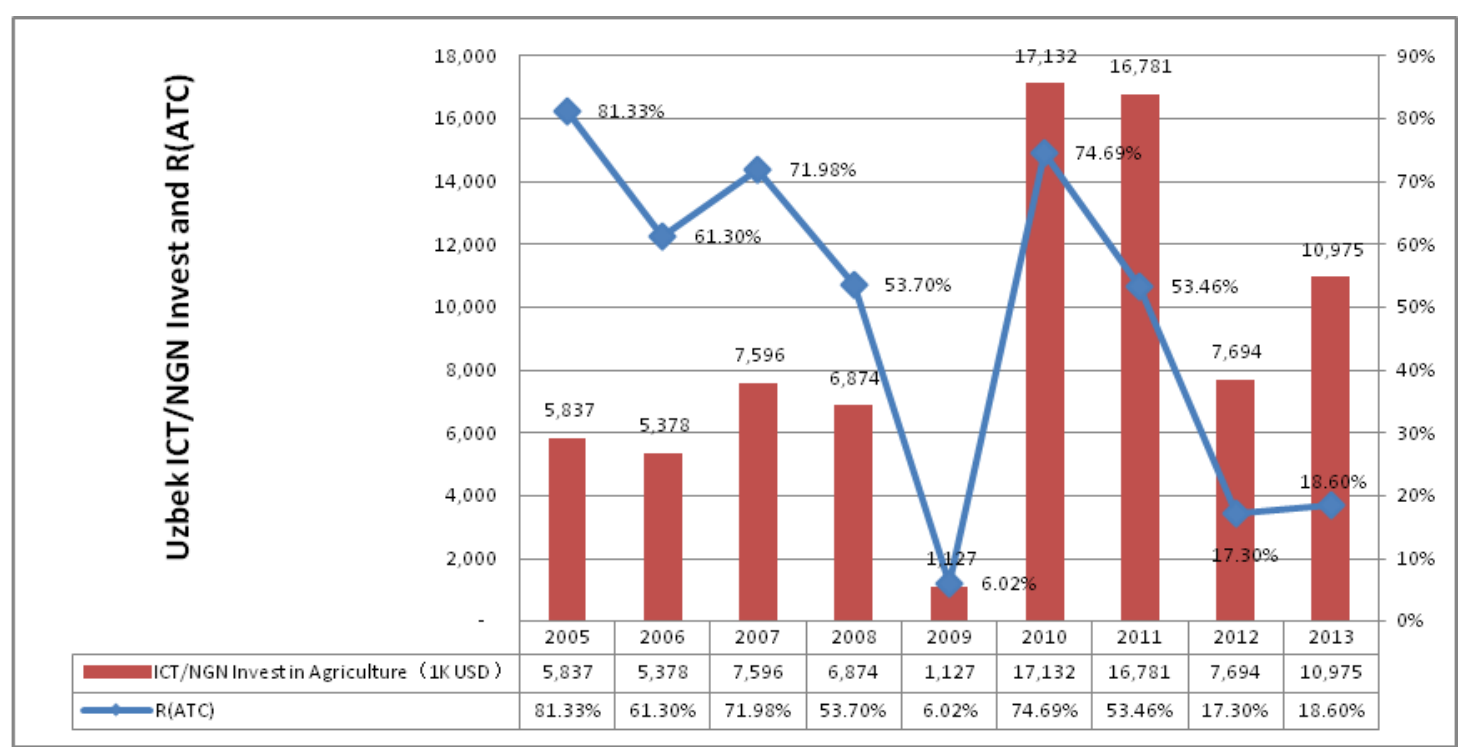

Graph 5: Uzbek ICT/NGN Invest and $R_{\text {ATC }}$ during 2005-2013 (Huawei Tashkent Database,
2014)

After the regress analysis between ICT/NGN investment in Agriculture in Uzbekistan and $\mathrm{R}_{\text {ATC, }}$ we get the coefficient rate is 0.3174 . the relation between them is positive, and $31.74 \%$ ICT/NGN investment increase rate will be converted to the $\mathrm{R}_{\mathrm{ATC}}$.

\section{CONCLUSIONS AND RECOMMENDATIONS}

From the data analysis, we find that the RATC is about $48 \%$ in Uzbekistan in 2013, it was the number in China in 2005. Currently, RATC is 54\% in 2013 in China, USA and developed countries is around $80 \%$. In the meanwhild, from the coeffice caculation via Cobb-Douglas production function, Labor, land and Material Coefficient are 0.095433, 0.397279 and 0.943074, it was meaning Labor and land factor in Agriculture in Uzbekistan is doing less contribution than Material expenditure. It is meaning, the material investment in Agriculture is still very important for Agriculture development, and the same situation all over the world for the developing countries.

ICT/NGN investment in Agriculture and RATC shows the positive relation, the coefficent ratio is 0.3174 . In order to imporve the RATC, ICT/NGN investment in Agriculture is quite important. It will fast up the $\mathrm{R}_{\text {ATC }}$ increase. From out research, among the land, labor and material expenditure input in Agriculture, the material input, such as seeds, irrigation water, chemical fertilization, machine and tract, is still the key factor for Agriculture output because its coefficient number is more than $90 \%$ between input and output. So current stage in Uzbekistan, Material input in Agriculture shall be kept on strength to make sure the Agriculture output is under managed. But the input factor shall be optimized and care more about the chemical fertilization and pesticides usage to prevent the soil pollution which happened in China and European countries.

In the other hand, enhance the ICT/NGN investment in Agriculture. Although the correlation between ICT/NGN investment in Agriculture and RATC is around 30\%, the number is variable when the science and technology development in Agriculture is a long term issue. In the meanwhile, any technology implementation has strong relation with human resource knowledge background. To improve the education and training of farmers will take time.

The potential of ICT/NGN investment for Agriculture to develop the area is quite big. As we mentioned, the number $\mathrm{R}_{\text {ATC }}$ in Uzbekistan in 2013 is 48\%, China in 2013 is about 54\%, and America and European Developed countries are around $70 \%$. To reach the level of America, China will take 20-30 years. The annual average improvement ratio is $1 \%$. The budgeting for ICT/NGN shall be lasted without stop. Currently the investment in ICT/NGN area is $0.4 \%$ of GDP, 4.4\% in US in 2008 (Andrew, 2010), and less than one tenth of it is put into Agriculture. So the amount of ICT/NGN in Agriculture shall be improved accordingly. The growth ratio in ICT/NGN investment in Agriculture shall not less than the investment in ICT/NGN in the society. And the ICT/NGN investment in the social shall be fast up, and the year to year growth ratio shall keep the same pace with the GDP growth. 
Tursun Shodiev, QiJu Zhu

Contribution Analysis of ICT (New Generation Network) Investment for Agriculture In Uzbekistan

\section{REFERENCES}

- Agriculture Science and Technology Contribution Statistic and Forecasting of Year 2020, Research Of Agricultural Modernization, Vol 27, Periodicals 7

- Andrew Sharpe(2010.2), The Canada-U.S. ICT Investment Gap in 2008, CSLS Research Note 2010-01

- Fan Sheng Gen, Xing Li (2007.1) The Introduction of Present measurement of Agriculture Technology Contribution, Chinese Academy of Agricultural Sciences, the 163th periodical

- http://www.tradingeconomics.com/uzbekistan/agricultural-land-sq-km-wb-data.html

- http://ageconsearch.umn.edu/bitstream/114563/2/Hasanov_Shavkat_674.pdf

- Ibrahim Yilmaz, Handan Akcaoz, Burhan Ozkan(2004.6), An analysis of energy use and input costs for cotton production in Turkey, Faculty of Agriculture, Department of Agricultural Economics, University of Akdeniz, Antalya

- $\quad$ State Committee for Land Resources (SCLR), 2002.

http://www.fao.org/docrep/006/y4711e/y4711e04.htm

- Wang QiXian, Li ZhiQiang, and Liu ZhenHu, Liu ZiJie(2006.11) the $10^{\text {th }} 5$ year China

- World Bank Indicators - uzbekistan - Agricultural production http://www.tradingeconomics.com/uzbekistan/agricultural-machinery-tractors-wb-data.html

- Zvi Lerman(2007), Department of Agricultural Economics and Management, The Hebrew University of Jerusalem, Israel

- http://www.tradingeconomics.com/uzbekistan/agricultural-land-sq-km-wb-data.html

- $\quad$ State Committee for Land Resources (SCLR), 2002. http://www.fao.org/docrep/006/y4711e/y4711e04.htm,

- http://www ageconsearch.umn.edu/bitstream/114563/2/Hasanov_Shavkat_674.pdf

- World Bank Indicators - uzbekistan - Agricultural production http://www.tradingeconomics.com/uzbekistan/agricultural-machinery-tractors-wb-data.html 